\title{
ANALISIS SENJATA KIMIA MELALUI UJI PROFISIENSI ORGANISATION PROHIBITION OF CHEMICAL WEAPON (OPCW)
}

\author{
Evita Boes, Dyah Styarini, Nuryatini \& Harry Budiman
}

\begin{abstract}
Identification of some chemicals weapons in the water and organic sample has been carried out during 21th proficiency testing conducted by OPCW (Organisation Prohibition of Chemical Weapon). The samples were prepared and analysed in accordance with the principles describe in the work instructions for the preparation of test samples for OPCW proficiency test. The extract of samples were analysed and identified by GC-EI-MS, GCCI-MS, GC-FPD, GC-NPD and LC-MS. From 7 spiking chemical weapons introduced to water and organic sample, 3 spiking chemicals could be identified such as Bis(2,4,4 trimethylpentyl)methylphosphonate, 2-(N-Ethyl$\mathrm{N}$-isoprophylamino)etanol and Bis(2-diisoprophylaminoethyl)disulfide.
\end{abstract}

Keywords: Chemical Weapon, proficiency test

\section{PENDAHULUAN}

Upaya pelarangan senjata kimia telah dimulai sejak tahun 1874, tetapi senjata kimia masih tetap dipakai dalam Perang Dunia I dan mengakibatkan korban \pm 100.000 jiwa meninggal dan sekitar satu juta orang cedera. Pada tanggal 3 September 1992, konferensi Perlucutan senjata kimia di Jenewa berhasil merampungkan negosiasinya dan mengesahkan teks Konvensi Pelarangan Menyeluruh Senjata Kimia (KPMSK). Pada tanggal 13 Januari 1993 diadakan penandatanganan KPMSK di Paris, di mana 130 negara menandatanganinya dan Indonesia telah mendepositkan piagam ratifikasi kepada Sekjen PBB pada tanggal 12 November 1998. Selain mematuhi dan melaksanakan semua ketentuan KPMSK, Indonesia diminta ikut dalam bagian tim verifikasi KPMSK.

Berdasarkan konvensi senjata kimia dan tingkat toksisitasnya maka toxic chemical dan precursor dibagi ke dalam tiga kategori yaitu schedule I merupakan daftar toxic chemical dan precursor yang memiliki resiko tinggi dan sangat mungkin digunakan untuk kegiatan yang dilarang oleh konvensi, schedule 2 merupakan daftar toxic chemical dan precursor yang memiliki resiko cukup tinggi dan mempunyai sifat mematikan dan mengakibatkan tidak berfungsinya organ tubuh, dan yang terakhir schedule 3 merupakan daftar toxic chemical dan precursor yang mungkin digunakan untuk kegiatan-kegiatan yang dilarang oleh konvensi $(1,2,3)$.

Maksud dari uji profisiensi yang diselenggarakan oleh OPCW adalah untuk melihat kemampuan dari laboratorium yang melakukan pengujian bahan senjata kimia, precursor dan hasil degradasinya serta memelihara prosedur standar (Recommended Operating Procedure - ROP) yang sudah distandarkan oleh OPCW bersama dengan laboratorium VERIFIN, Universitas Helsinki, Finland. Direktur Jenderal OPCW mengakreditasi laboratorium yang berkualitas berdasarkan hasil analisa sampel yang dikirimkan oleh OPCW. Sekretariat OPCW juga mengakomodasi semua laboratorium yang ingin ikut berpartisipasi dalam uji profisiensi dan yang sedang mencari predikat laboratorium yang terakreditasi untuk analisa senjata kimia. Dalam pelaksanaannya sekretariat OPCW dibantu oleh dua laboratorium yang telah terakreditasi dengan tugas untuk mempersiapkan contoh dan pengemasannya dan satu laboratorium lagi untuk mengevaluasi hasil.

Contoh yang harus dianalisa terdiri dari senyawa senjata kimia yang ada dalam schedule chemicals (precursor, senyawa senjata kimia dan hasil degradasinya) atau unknown sebanyak 5 - 10 ppm. Hasil analisa contoh dari setiap laboratorium harus dilaporkan setelah 15 hari kerja sejak contoh diterima. Sampai saat ini OPCW telah menyelenggarakan uji profisiensi sebanyak 23 kali dan uji profisiensi yang ke 14, 15 dan 21 adalah uji profisiensi yang pernah diikuti oleh Indonesia yang diwakili oleh Puslit Kimia - LIPI.

Salah satu metode yang telah dikembangkan untuk menganalisis bahan dan hasil degradasi senjata kimia adalah metode kromatografi, baik kromatografi gas maupun kromatografi cair. Metode ini sangat cocok untuk digunakan dalam mengidentifikasi bahan maupun hasil degradasi senjata kimia karena mempunyai kemampuan akurasi dan sensitivitas yang tinggi. Metode Kromatografi Gas (GC) dan Kromatografi Gas Spektrometri Massa (GCMS) merupakan metode yang tepat dalam 
menganalisis bahan serta hasil degradasi senjata kimia. Beberapa hal yang menjadi masalah adalah: keberadaan senyawa kimia hasil degradasi senjata kimia di lingkungan (matriks) sangat kecil, senyawa-senyawa yang akan dianalisis mempunyai sifat yang tidak menguap (non-volatile compound), labil, sangat polar dan matriks yang mengandung senyawa yang kompleks. Langkah awal yang sangat penting dalam setiap analisis untuk mengidentifikasi senyawa senjata kimia dengan metode-metode di atas adalah persiapan contoh, yang sangat akan menentukan keberhasilan dalam mengidentifikasi senyawa senjata kimia $(4,5,6,7,8)$.

Dalam melaksanakan uji profisiensi yang pernah diikuti, belum diperoleh nilai yang memuaskan. Secara singkat hasil uji profisiensi berupa nilai A s/d F. Nilai A diperoleh bila seluruh senyawa senjata kimia ditemukan, nilai $B$ diperoleh bila satu saja senyawa senjata kimia tak dilaporkan, nilai $\mathrm{C}$ diperoleh bila setengah senyawa senjata kimia tak dilaporkan, nilai $D$ diperoleh bila lebih dari setengah jumlah senyawa senjata kimia tak dilaporkan dan nilai $F$ bila tidak melaporkan atau yang dilaporkan bukan senyawa senjata kimia (falsh positive). Apabila salah satu laboratorium dari Indonesia yang ikut serta melakukan uji profisiensi dari OPCW ini dan memperoleh predikat nilai $2 \times \mathrm{A}$ dan 1 x B maka akan berhasil menjadi laboratorium rujukan.

\section{METODOLOGI}

a. Contoh Uji Profisiensi ke 21

Dalam PT ke 21 ini ada 6 contoh yang dikirimkan untuk dianalisa. Contoh tersebut adalah organik (kode O), blanko sampel organik (kode OB), air (kode W1) dan blankonya (kode WB1) dan air (kode W2) dan blankonya (kode WB2). Adapun isi senyawa (spiking chemicals) dari contoh $\mathrm{O}$, W1, W2, dapat dilihat pada Tabel 1. Tahapan yang dilalui dalam analisa contoh dalam PT 21 adalah preparasi contoh, analisa dengan GC-FPD, GC-MS-EI, GCMS-Cl dan LC-MS. Hasil analisis contoh harus dilaporkan pada hari ke 15 dihitung hari ke 1 adalah pada saat contoh diterima di laboratorium

b. Persiapan Contoh Organik

Preparasi terhadap contoh dengan kode $\mathrm{O}$ beserta blanko dilakukan sesuai dengan prosedur standar (Recommended Operating Procedure - ROP) yang sudah distandarkan oleh pihak penyelenggara (OPCW) bersama dengan Laboratorium VERIFIN, Universitas Helsinki, Finland. Sebanyak 1 - $10 \mu$ hasil ekstraksi sampel organik diinjeksikan ke peralatan GC-FPD, GC-EI-MS, GC-Cl-MS dan LC-MS. Hasil preparasi pertama kali dianalisis dengan GC-FPD untuk screening dan kemudian diinjeksikan ke GC-MS untuk mengetahui waktu retensi dan spektrum dari masing-masing puncak dalam Total Ion Chromatography (TIC) yang dihasilkan. Sedangkan LC-MS digunakan untuk konfirmasi berat molekul dari GC-Cl-MS yang dihasilkan. Puncak pada TIC dari setiap sampel yang diinjeksikan dievaluasi dengan menggunakan Automated Mass Spectral Deconvolution and Identification System (AMDIS) dan National Institute of Standards and Technology (NIST).

c. Persiapan Contoh Air

Preparasi terhadap contoh dengan kode W1 dan W2 beserta blanko dari masing-masing sampel sama dengan point 2 di atas yaitu menggunakan ROP yang telah distandarkan oleh OPCW bersama dengan laboratorium VERIFIN, Universitas Helsinki, Finland. Sebanyak 1 - $10 \mu$ l hasil ekstraksi sampel air diinjeksikan ke GC-FPD, GC-EI-MS, GC-ClMS dan LC-MS

d. Identifikasi dengan GC Identifikasi dengan GC-FPD menggunakan gas pembawa helium dengan kecepatan alir $1 \mathrm{ml} / \mathrm{menit}$ Injeksi dilakukan splitless, temperatur injektor $250^{\circ} \mathrm{C}$. Temperatur kolom terprogram, temperature awal $40^{\circ} \mathrm{C}(2$ menit), rate $10^{\circ} \mathrm{C} /$ menit, temperatur akhir $280^{\circ} \mathrm{C}$ (4 menit). Kolom yang digunakan adalah DB5 (30 m x 0,25 mm x 0,25 $\mu \mathrm{m}$ )

e. Identifikasi dengan GC-MS

Menggunakan gas pembawa helium, diatur pada kecepatan alir $1 \mathrm{ml} /$ menit. Injeksi dilakukan splitless, temperatur injector $260^{\circ} \mathrm{C}$. Temperatur kolom terprogram, temperatur awal $40^{\circ} \mathrm{C}$ (2 menit), rate $100 \mathrm{C} /$ menit, temperatur akhir $280^{\circ} \mathrm{C}$ (4 menit). Energi elektron $70 \mathrm{eV}$, scan range $40-400 \mathrm{~m} / \mathrm{z}$ (mode El), 60 - $400 \mathrm{~m} / \mathrm{z}$ (mode $\mathrm{Cl}$ ), gas reaksi isobutana untuk mode $\mathrm{Cl}$.

f. Identifikasi dengan LC-MS

Teknik elusi yang digunakan adalah isokratik dengan komposisi eluen methanol : air dengan perbandingan 30 : 70. Kecepatan alir $1 \mathrm{ml} / \mathrm{menit}$, kepolaran ionisasi : positif, elektrospray voltage $84 \mathrm{kV}$, scan range $100-1000 \mathrm{~m} / \mathrm{z}$

g. Evaluasi Menggunakan AMDIS

AMDIS adalah perangkat lunak untuk menyelesaikan masalah-masalah dengan metode identifikasi yang menggunakan GC- 
MS untuk memverifikasi senyawa senjata kimia (The Chemical Weapons Compound). Dari hasil analisis dengan GC-MS data dievaluasi menggunakan AMDIS, senyawa target akan diperoleh dalam bentuk spektrum massa yang murni dan kemudian dapat dicocokkan spektrum massa murni ini dengan senyawa dalam library. Senyawa yang paling cocok spektrum massanya dengan spektrum massa dalam library kemudian dapat dilaporkan sebagai senyawa target.

\subsection{Reagen/Pereaksi yang Digunakan}

Pelarut organik: asetonitril, diklorometane, heksan, trietilamin dan metanol dengan kualitas kromatografi dan pereaksi derivatisasi. Gas helium, nitrogen, hydrogen, isobutana dengan kualitas UHP.

\subsection{Alat yang Digunakan}

a. Gas Chromatography Shimadzu dengan Flame Photometric Detector (FPD) menggunakan kolom DB5

b. Gas Chromatography Mass Spectrometer (GC/MS) Shimadzu QP 2010 menggunakan kolom DB-5MS (30 m x 0,25 mm x 0,25 $\mu \mathrm{m})$ dengan mode Electron Impact Ionization (EI) dan Chemical Ionization (Cl)

c. Liquid Chromatography Mass Spectrometer (LC-ESI MS) Biospectrometry menggunakan kolom Vydac (25 mm x $2 \mathrm{~mm} \times 5 \mu \mathrm{m})$

\section{HASIL DAN PEMBAHASAN}

Pada kegiatan uji profisiensi, setiap laboratorium peserta diberikan waktu 15 hari sejak contoh diterima oleh laboratorium untuk menyelesaikan analisis termasuk pelaporan. Semua contoh uji yang diterima disimpan pada suhu $4^{\circ} \mathrm{C}$ sebelum dipreparasi untuk menghindari terjadinya kerusakan terhadap contoh uji tersebut. Preparasi contoh uji dilakukan dengan menggunakan prosedur yang telah distandarkan oleh pihak penyelenggara yaitu OPCW yang bekerjasama dengan laboratorium VERIFIN, Universitas Helsinki, Finland. Dengan demikian diharapkan dapat diperoleh hasil analisis yang maksimal dengan kesalahan sekecil mungkin selama pengerjaan contoh uji. Adapun isi senyawa (spiking chemicals) dari contoh $\mathrm{O}, \mathrm{W} 1$, W2, dapat dilihat pada Tabel 1 sedangkan senyawa hasil identifikasi pada contoh organik (O) dan Air (W1 dan W2) ditunjukkan dalam Tabel 2.

\subsection{Hasil Analisis Contoh Organik Pada Uji Profisiensi 21}

Pada Tabel 1 dapat dilihat 7 buah senyawa spiking chemical yang ditambahkan pada contoh organik dan contoh air oleh laboratorium yang ditunjuk oleh OPCW sebagai laboratorium penyiap contoh.

Hasil analisis terhadap contoh organik menunjukkan bahwa dari 3 spiking chemical hanya ditemukan 1 buah senyawa setelah di preparasi dengan menggunakan Solid Phase Extraction (SPE). Senyawa yang ditemukan adalah $\operatorname{Bis}(2,4,4$ trimetilpentil)metilfosfonat seperti pada Gambar 1.

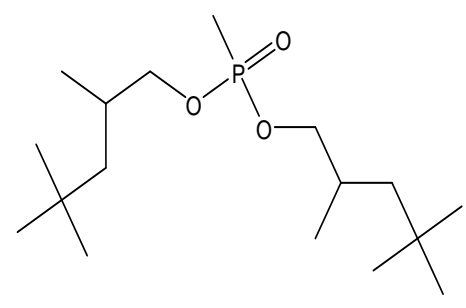

\section{Gambar 1 Struktur Bis \\ (2,4,4 trimetilpentil) Metilfosfonat}

Identifikasi senyawa ini dilakukan dengan menggunakan GC-EI-MS dan GC-Cl-MS. Puncak dengan intensitas kuat muncul pada waktu retensi 19,87 menit pada Total Ion Chromatogram (TIC) GC-EI-MS, seperti pada gambar 2a, sedangkan pada blankonya hanya nampak noise pada TIC, seperti Gambar 2b.

Spektrum yang dihasilkan dari puncak 19,876 menit menunjukkan adanya $\mathrm{m} / \mathrm{z}$ 97; [CH6PO3]+ yang karakteristik untuk senyawa golongan dialkyl methylphosphonate, seperti pada Gambar 3.

Spektrum yang didapatkan ini kemudian dibandingkan dengan database spektrum dari OPCW Central Analytical database (OCAD) library, hasil perbandingan menunjukkan spektrum di atas merupakan spektrum untuk senyawa Bis(2,4,4-trimetilpentil) metil fosfonat. Data dari GC-El-MS ini diperkuat dengan data yang dihasilkan dari GC-Cl-MS. Senyawa ini muncul pada waktu retensi 19,855 mnt seperti pada Gambar 4, dan memiliki berat molekul 321 $[\mathrm{M}+\mathrm{H}]+$ pada spektrumnya, seperti pada Gambar 5, yang mengindikasikan keberadaan senyawa Bis $(2,4,4$ trimetilpentil) metil fosfonat dengan berat molekul 320. Senyawa ini merupakan senyawa schedule 2 dalam Chemical Weapon Convention (CWC) dan biasa ditemukan sebagai pengotor atau produk samping pada sintesis senyawa senjata kimia golongan metilfosfonatfluoridat. 
Tabel 1 Daftar Senyawa Spiking pada Profisiensi Testing ke-21

\section{Contoh Organik}

\begin{tabular}{|c|c|c|c|c|c|c|}
\hline $\begin{array}{c}\text { Sample } \\
\text { code }\end{array}$ & $\begin{array}{l}\text { Chemical } \\
\text { number }\end{array}$ & Chemical name & \begin{tabular}{|c|} 
Chemical \\
Abstract Service \\
number
\end{tabular} & Chemical Structure & $\begin{array}{l}\text { Molecular } \\
\text { formula }\end{array}$ & $\begin{array}{l}\text { Schedule } \\
\text { number }\end{array}$ \\
\hline $\mathrm{O}$ & $\bar{A}$ & 2-Chlorovinyldichloroarsine & $541-25-3$ & $\mathrm{Cl}$ & $\mathrm{C}_{2} \mathrm{H}_{2} \mathrm{AsCl}_{3}$ & 1. A.05 \\
\hline $\mathrm{O}$ & $B$ & $\begin{array}{l}\text { Bis (2-chlorovinyl) } \\
\text { chloroarsine }\end{array}$ & $40334-69-8$ & & $\mathrm{C}_{4} \mathrm{H}_{4} \mathrm{AsCl}_{3}$ & 1. A.05 \\
\hline $\mathrm{O}$ & $\mathrm{C}$ & $\begin{array}{l}\text { Bis }(2,4,4 \text { trimethylpentyl) } \\
\text { methylphosphonate }\end{array}$ & & & $\mathrm{C}_{17} \mathrm{H}_{37} \mathrm{O}_{3} \mathrm{P}$ & 2.B.04 \\
\hline
\end{tabular}

\section{Contoh Air}

\begin{tabular}{|c|c|c|c|c|c|c|}
\hline $\begin{array}{c}\text { Sample } \\
\text { code }\end{array}$ & $\begin{array}{l}\text { Chemical } \\
\text { number }\end{array}$ & Chemical name & $\begin{array}{c}\text { Chemical } \\
\text { Abstract } \\
\text { Service } \\
\text { number }\end{array}$ & Chemical Structure & $\begin{array}{c}\text { Molecular } \\
\text { formula }\end{array}$ & $\begin{array}{c}\text { Schedule } \\
\text { number }\end{array}$ \\
\hline W1 & $\mathrm{D}$ & $\begin{array}{l}\text { Methylphosphonic } \\
\text { acid }\end{array}$ & $993-13-5$ & $\mathrm{HO}-\left.\right|_{\mathrm{P}} ^{\mathrm{OH}}=\mathrm{O}$ & $\mathrm{CH}_{5} \mathrm{O}_{3} \mathrm{P}$ & 2.B.04 \\
\hline W2 & $E$ & $\begin{array}{l}\text { 2-(N-N- } \\
\text { Diisopropylamino) } \\
\text { ethane sulfonic acid }\end{array}$ & $128869-82-69$ & & $\mathrm{C}_{8} \mathrm{H}_{19} \mathrm{NO}_{3} \mathrm{~S}$ & $\begin{array}{l}\text { Reaction } \\
\text { Product }\end{array}$ \\
\hline W2 & $\mathrm{F}$ & $\begin{array}{l}\text { 2-(N-etil-N-isopropil } \\
\text { amino)etanol }\end{array}$ & $2893-61-0$ & & $\mathrm{C}_{7} \mathrm{H}_{17} \mathrm{NO}$ & $2 . B .11$ \\
\hline W2 & $\mathrm{G}$ & $\begin{array}{l}\text { Bis(2-N,N- } \\
\text { diisopropilaminoetil)d } \\
\text { isulfida }\end{array}$ & $65332-44-7$ & & $\mathrm{C}_{16} \mathrm{H}_{36} \mathrm{~N}_{2} \mathrm{~S}_{2}$ & $\begin{array}{l}\text { Reaction } \\
\text { Product }\end{array}$ \\
\hline
\end{tabular}


Analisis Senjata Kimia melalui Uji Profisiensi (Evita B, Dyah S, Nuryatini, Harry B)

Tabel 2 Hasil Analisis Sampel PT 21 th

\begin{tabular}{|c|c|c|c|c|c|c|c|}
\hline $\begin{array}{c}\text { Sample } \\
\text { code }\end{array}$ & $\begin{array}{l}\text { Chemical } \\
\text { number }\end{array}$ & $\begin{array}{l}\text { Chemical } \\
\text { name }\end{array}$ & $\begin{array}{c}\text { Chemical } \\
\text { Abstract } \\
\text { Service } \\
\text { number }\end{array}$ & Chemical Structure & $\begin{array}{l}\text { Molecular } \\
\text { formula }\end{array}$ & $\begin{array}{l}\text { Schedule } \\
\text { number }\end{array}$ & Comments \\
\hline $\mathrm{O}$ & 1 & $\begin{array}{l}\mathrm{Bis}\left(\mathrm{C}_{8} \mathrm{H}_{17^{-}}\right. \\
\text {alkyl) } \\
\text { methylphos } \\
\text { phonate }\end{array}$ & - & & 320 & 2.B.04 & $\begin{array}{l}2 \text { techniques } \\
\text { (GC EI/MS, } \\
\text { GC Cl/MS, } \\
\text { LC ESI/MS) }\end{array}$ \\
\hline W2 & 2 & $\begin{array}{l}\text { 2-(N-etil-N- } \\
\text { isopropil } \\
\text { amino)etano } \\
\text { I }\end{array}$ & $2893-61-0$ & & 131 & 2.B.11 & $\begin{array}{l}2 \text { techniques } \\
\text { (GC EI/MS, } \\
\text { GC CI/MS, } \\
\text { LC ESI/MS) }\end{array}$ \\
\hline W2 & 3 & $\begin{array}{l}\text { 2-(N,N- } \\
\text { diisopropyla } \\
\text { mino)ethane } \\
\text { thiol }\end{array}$ & $5842-07-9$ & & 161 & 2.B.12 & $\begin{array}{l}\text { techniques } \\
\text { (GC El/MS, } \\
\text { GC Cl/MS,) }\end{array}$ \\
\hline W2 & 4 & $\begin{array}{l}\text { Bis(2-N,N- } \\
\text { diisopropila } \\
\text { minoetil)dis } \\
\text { ulfida }\end{array}$ & $65332-44-7$ & & 320 & - & $\begin{array}{l}2 \text { techniques } \\
\text { (GC El/MS, } \\
\text { GC Cl/MS) }\end{array}$ \\
\hline
\end{tabular}

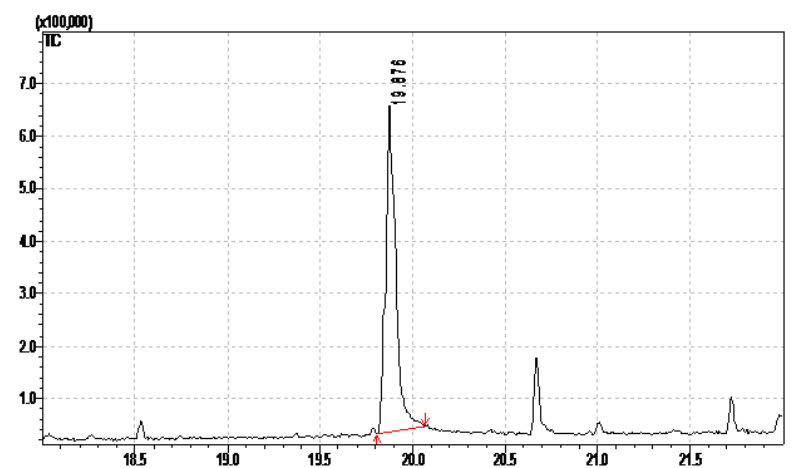

(a) Contoh

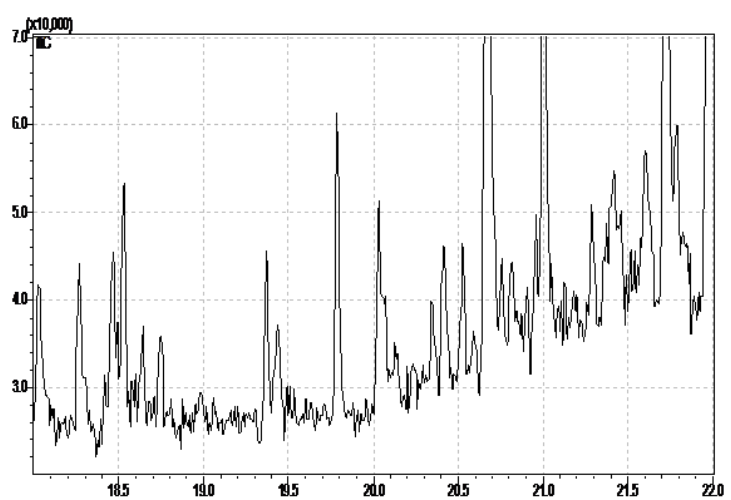

(b) Blanko

Gambar 2 TIC GC-EI-MS Contoh Organik (O) 


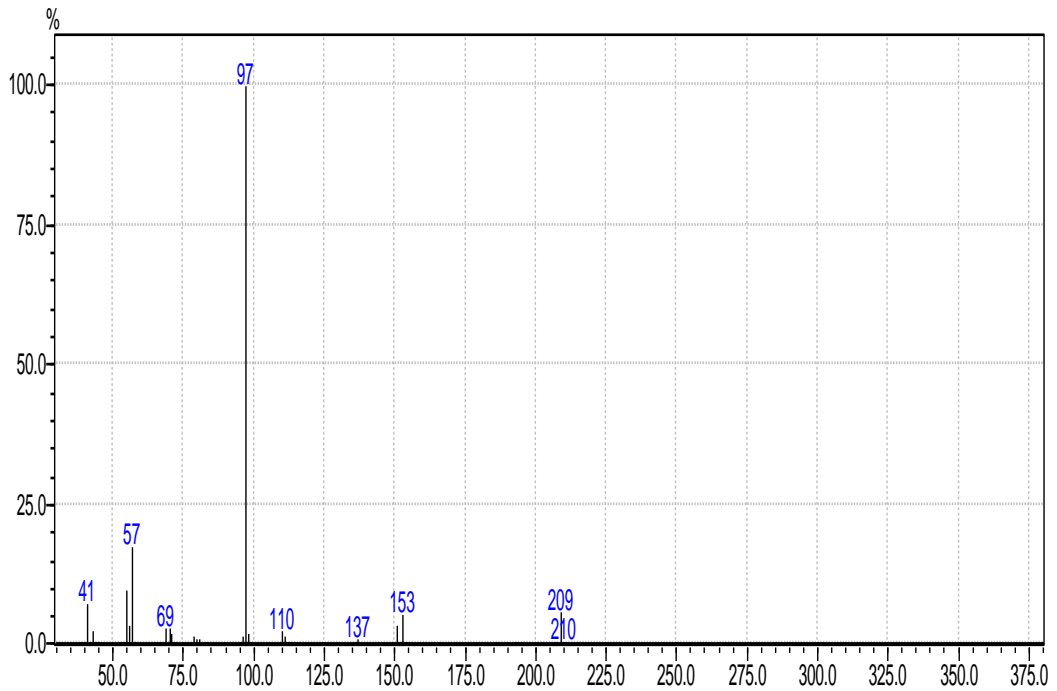

Gambar 3 Mass Spektrum GC-EI-MS dari Puncak 19,876 min pada Contoh Organik

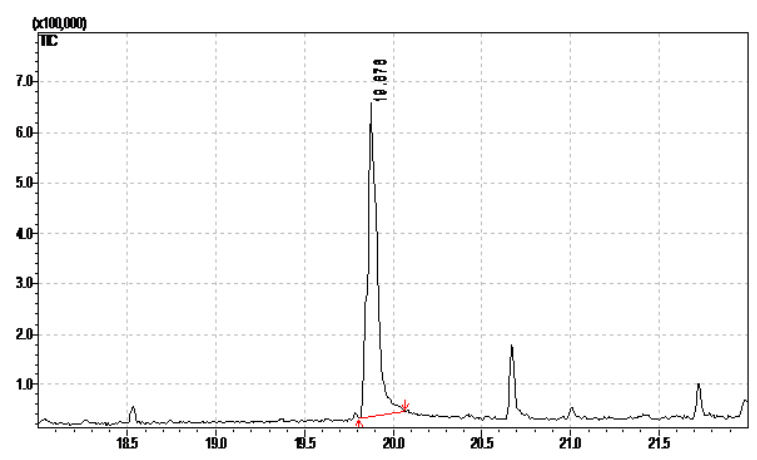

(a) Contoh

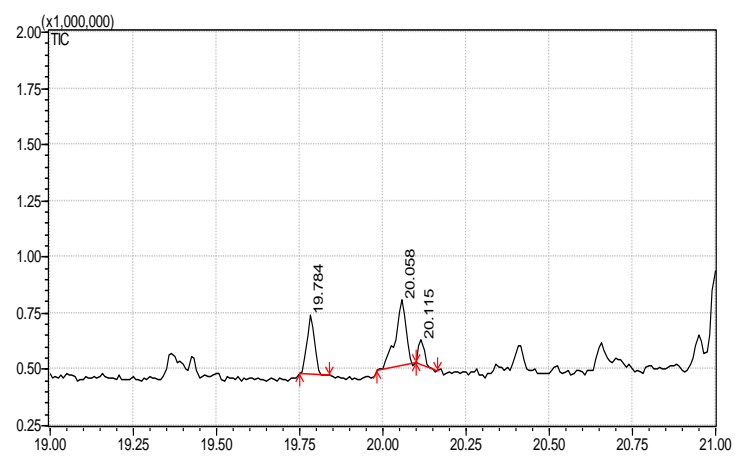

(b) Blanko

Gambar 4 TIC dari GC-EI-MS Contoh Organik (O)

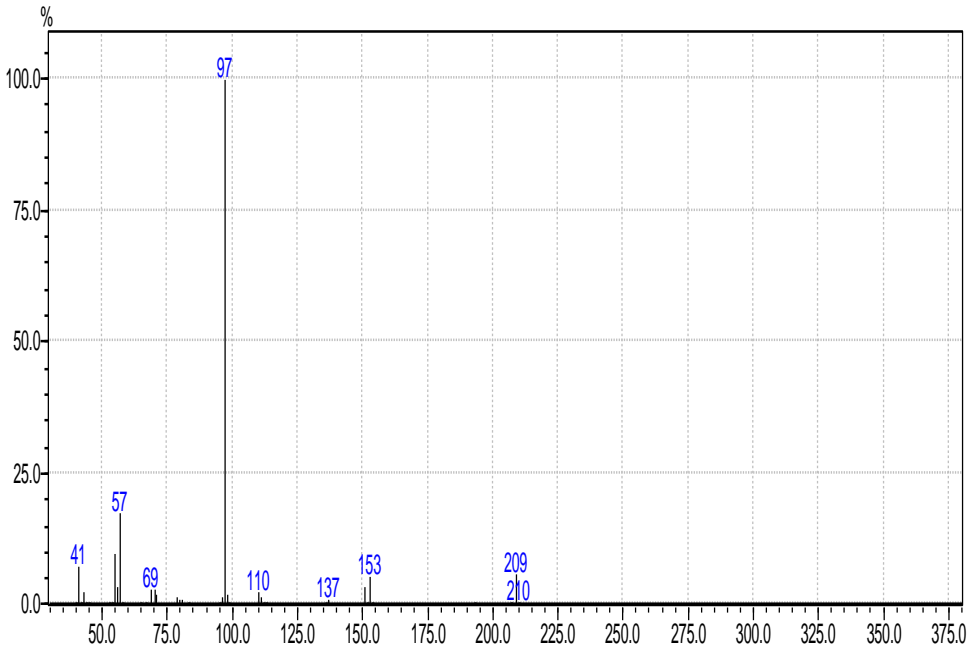

Gambar 5 Mass Spektrum GC-El-MS pada Puncak 19,876 mnt pada Contoh Organik 


\subsection{Hasil Analisis Contoh Air pada Uji Profisiensi 21}

Hasil analisis terhadap contoh air (W2) menunjukkan bahwa dari 3 spiking chemical hanya ditemukan 2 buah senyawa setelah dipreparasi dengan diklorometan pada $\mathrm{pH}$ netral yaitu 2-(N-etl-N-isopropilamino)etanol dan Bis(2$\mathrm{N}, \mathrm{N}$-diisopropilaminoetil)disulfide. Hasil analisis dengan GC-EI-MS puncak senyawa 2-(N-etil-Nisopropilamino) etanol mempunyai waktu retensi $8,008 \mathrm{mnt}$, seperti Gambar 6 dan spektrumnya menunjukkan adanya $\mathrm{m} / \mathrm{z} 100$ yang berasal dari fragmentasi $\left[\mathrm{C}_{6} \mathrm{H}_{2} \mathrm{~N}\right]^{+}$. Fragmentasi ini tebentuk akibat hilangnya molekul $-\mathrm{CH}_{2} \mathrm{OH}$ dari 2-(N-etil$\mathrm{N}$-isopropilamino)etanol.

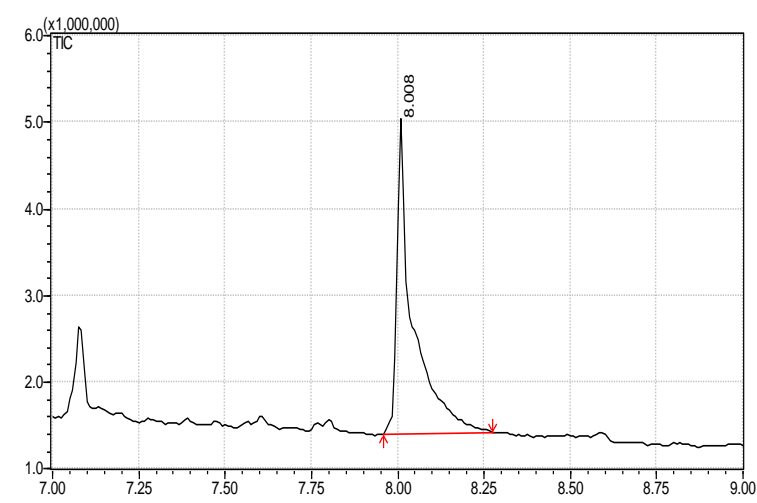

(a) Contoh
Perbandingan spectrum contoh dengan spectrum OCAD library memberikan hasil yang cocok untuk senyawa 2-(N-etil- $\mathrm{N}$-isopropil amino) etanol dengan fragmen pada $\mathrm{m} / \mathrm{z}: 58$, 100, 116, 131, seperti pada Gambar 7

Sedangkan TIC dari GC-Cl-MS pada $\mathrm{m} / \mathrm{z}$ 132 menandakan adanya senyawa 2-(N-etil- $\mathrm{N}$ isopropilamino)etanol pada waktu retensi 8,056, seperti pada Gambar 8. Ion m/z 132 untuk $[\mathrm{M}+\mathrm{H}]+$ pada mass spektrum puncak tersebut, seperti pada Gambar 9 menunjukkan berat molekul senyawa tersebut yaitu 131, yang merupakan berat molekul dari senyawa 2-(N-etil$\mathrm{N}$-isopropilamino)etanol. Senyawa ini diklasifikasikan sebagai senyawa schedule 2 dalam CWC dan termasuk dalam precursor atau reaktan untuk mensintesis schedule 1.

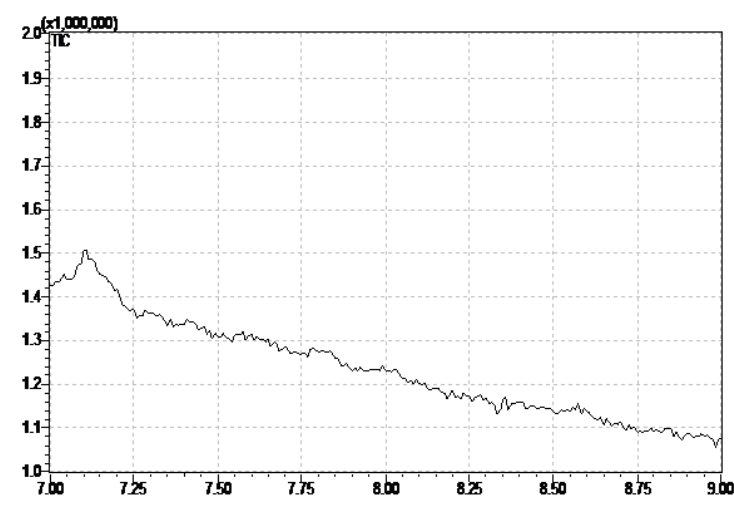

(b) Blanko

Gambar 6 TIC dari GC-EI-MS pada Contoh Air W2

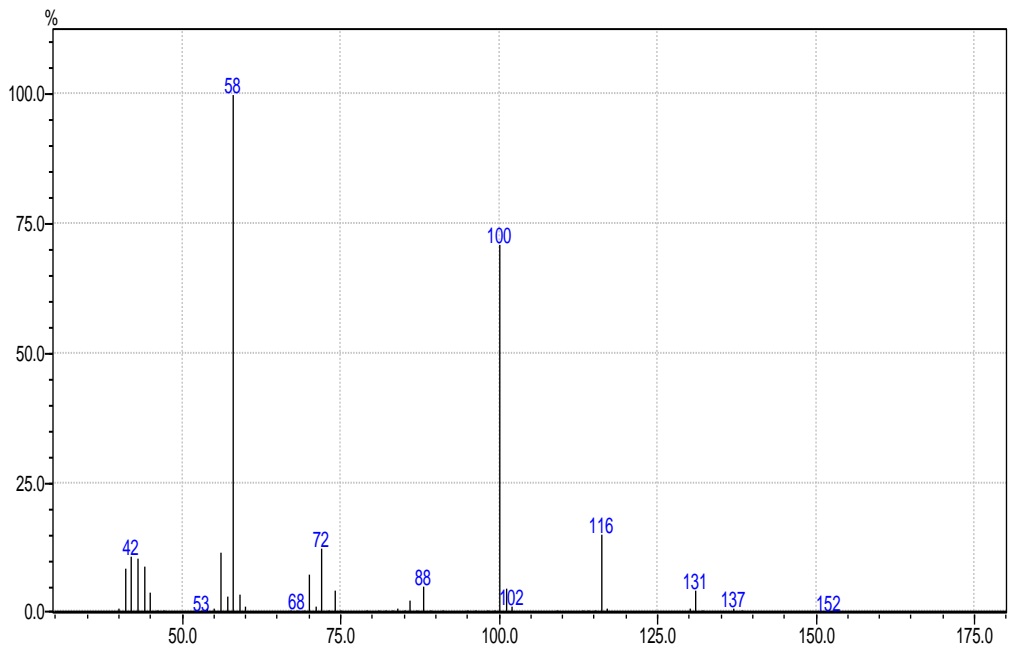

Gambar 7 Mass Spektrum GC-EI-MS dari Puncak 8,008 mnt pada Contoh Air W2 


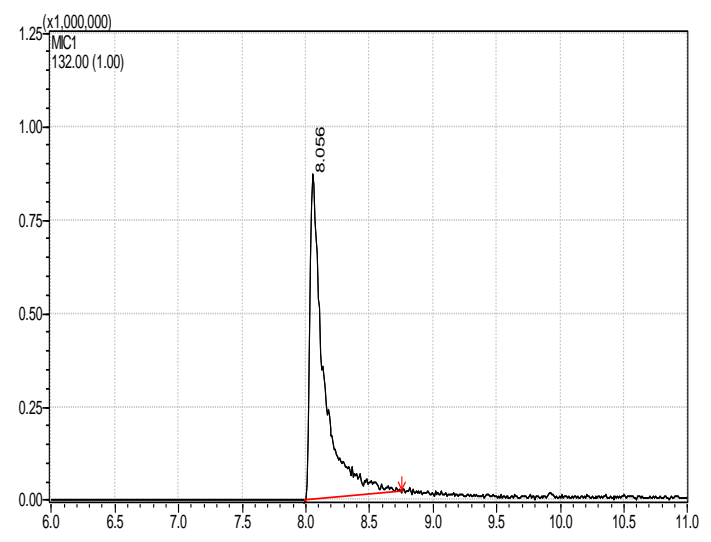

(a) Contoh

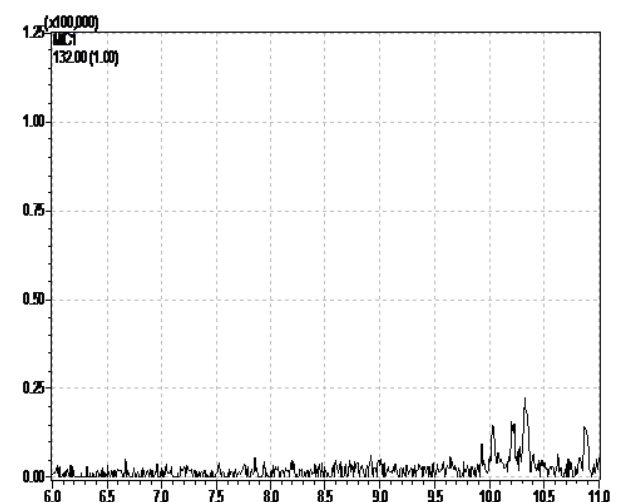

(b) Blanko

Gambar 8 TIC dari GC-CI-MS Contoh Air (W2)

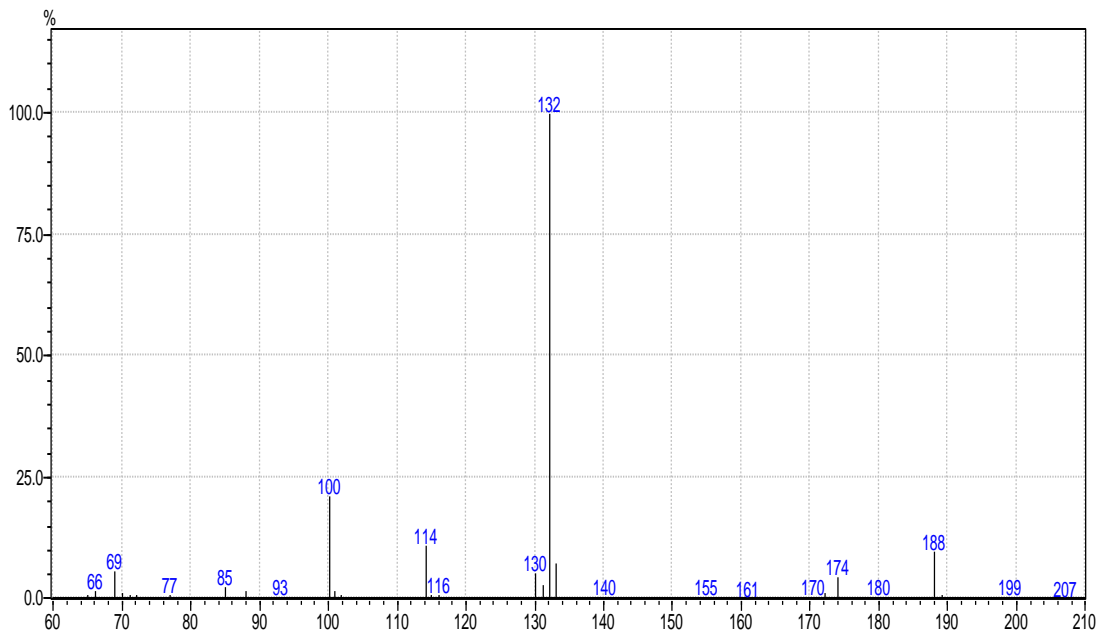

Gambar 9 Mass Spektrum GC-Cl-MS dari Puncak 8,056 mnt pada Contoh Air (W2)

Hasil analisis GC-MS ini diperkuat oleh hasil analisis pada contoh W2 (sebagai original sample) dengan menggunakan LC-ESI-MS yang menunjukkan adanya puncak pada waktu retensi 3,0 mnt seperti pada Gambar 10, lihat juga kromatogram blankonya pada Gambar 11. Puncak pada waktu retensi 3,0 mnt tersebut memiliki mass spectrum diantaranya $[\mathrm{M}+\mathrm{H})^{+}$ 132,009, seperti terlihat pada Gambar 12 yang artinya terdapat senyawa dengan berat molekul 131 yaitu 2-(N-etil-N-isopropilamino)etanol.

Senyawa kedua yang ditemukan pada contoh air W2 adalah Bis (2-N,Ndiisopropilaminoetil) disulfide dilakukan dengan menggunakan GC-EI-MS dan GC-Cl-MS. Pada
TIC dari GC-El-MS, puncak senyawa ini ditemukan pada waktu retensi 21,932 mnt, seperti pada Gambar 13, adanya fragmen dengan nilai $\mathrm{m} / \mathrm{z} 114\left[\mathrm{C}_{6} \mathrm{H}_{14} \mathrm{~N}\right]^{+}$pada massa spectrum puncak tersebut, seperti pada Gambar 14, mengindikasikan adanya senyawa golongan VX (O-alkyl, S-2-diisopropilaminoethyl alkylphosphonothiolate) atau degradasi produknya yaitu 2-N,N-diisopropylaminoetyl sulfida. Mass spectrum puncak tersebut diidentifikasi sebagai senyawa Bis (2-N,Ndiisopropylaminoethyl) disulfide dengan berat molekul 320 setelah dibandingkan dengan masa spectrum dari OCAD library. 


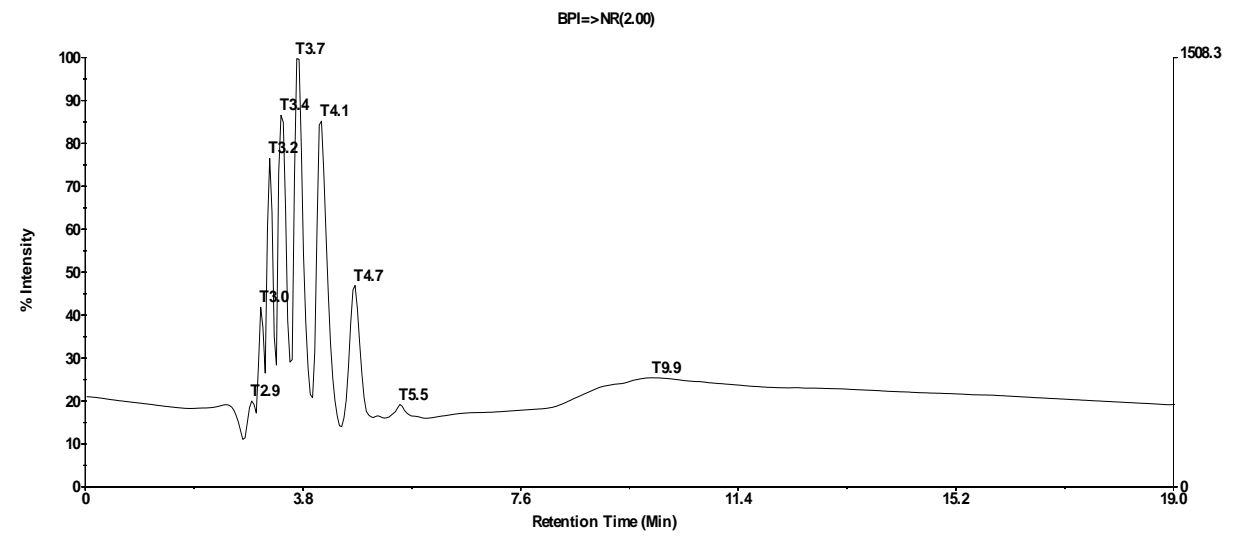

Gambar 10 Kromatogram LC-ESI-MS Pos Ion dari Contoh W2

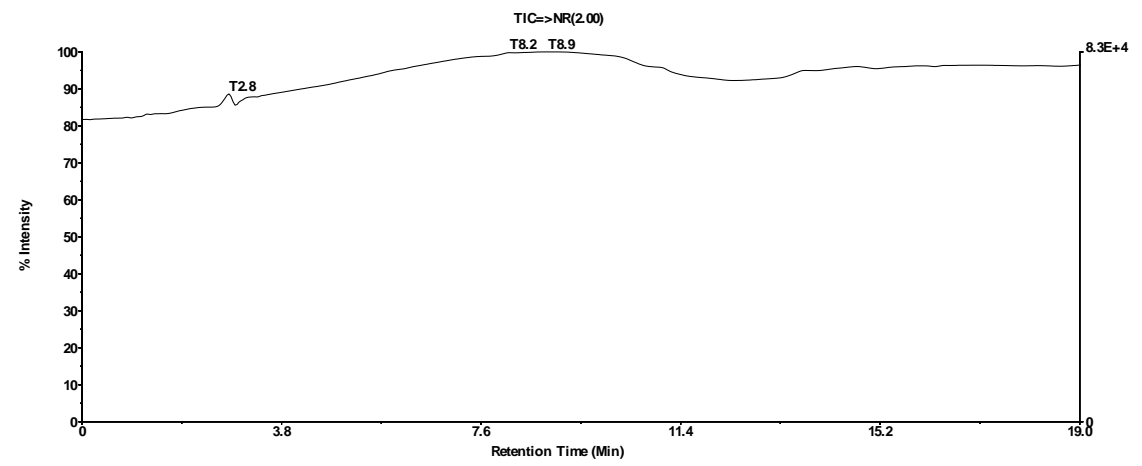

Gambar 11 Kromatogram LC-ESI-MS Pos Ion dari Blanko W2

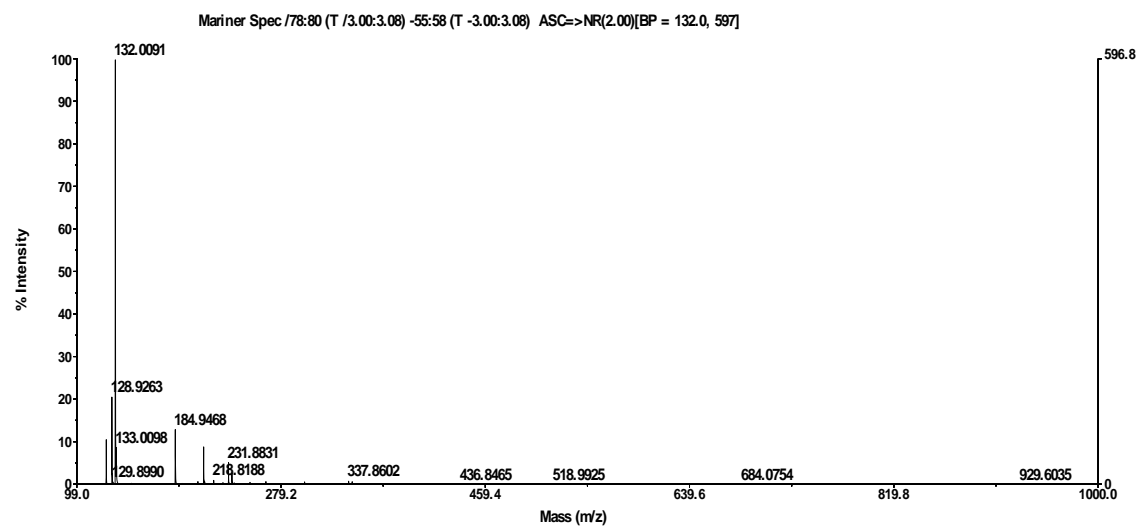

Gambar 12 Spektrum Massa LC-ESI-MS dari Contoh Air W2 pada Waktu Retensi 3 mnt

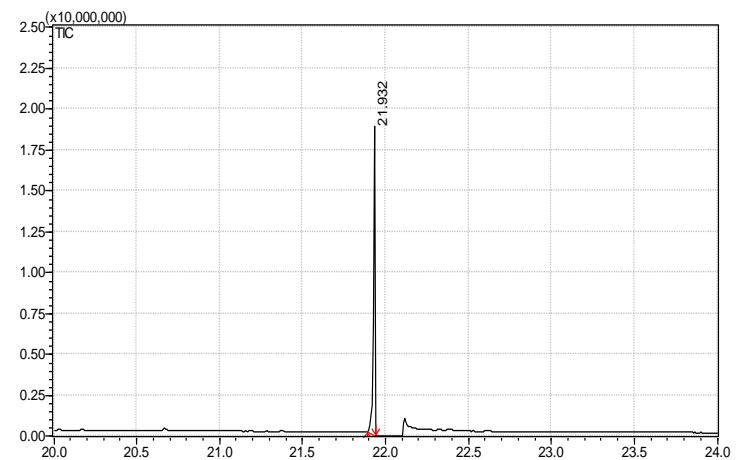

(a) Contoh

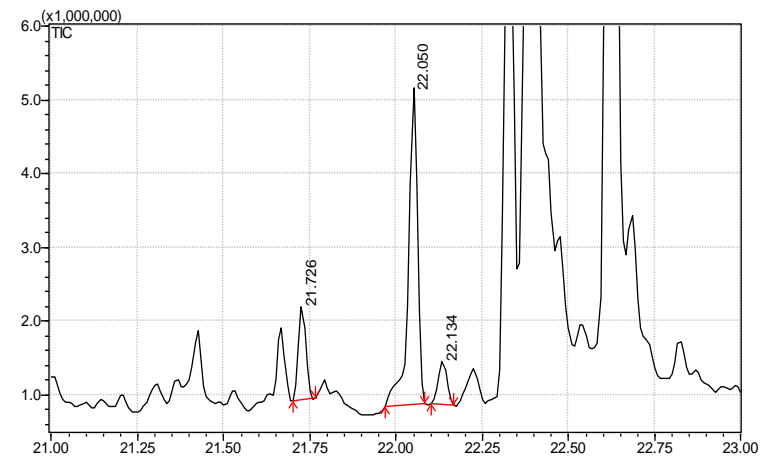

(b) Blanko

Gambar 13 TIC GC-El-MS Contoh Air (W2) 


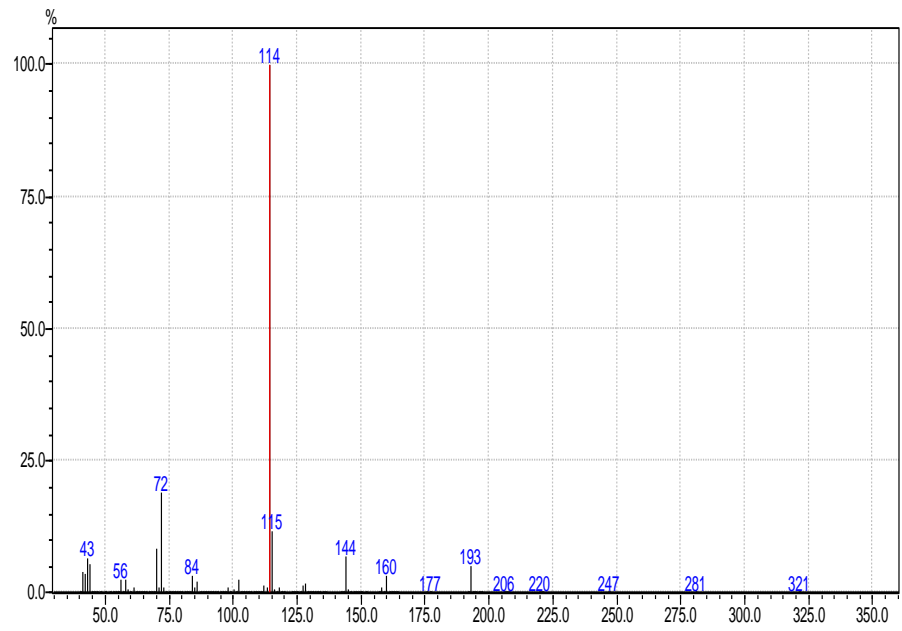

Gambar 14 Mass Pektrum GC-EI-MS dari Puncak 21,39 mnt pada Contoh Air (W2)

\section{KESIMPULAN}

Hasil kegiatan analisis senyawa senjata kimia dan bahan dan hasil degradasi senjata kimia pada PT 21 hanya dapat mengidentifikasi 3 senyawa dari 7 senyawa yang di-spiking. Hal ini disebabkan 2 senyawa senjata kimia pada contoh organik tidak ditemukan adalah Lewisite 1 dan Lewisite 2 disebabkan karena tidak tersedia reaksi untuk derivatisasi, dua senyawa senjata kimia juga tidak ditemukan pada contoh air. Selain dari pereaksi yang tidak tersedia juga perlu ditingkatkan kemampuan pada preparasi contoh yang merupakan hal paling penting pada identifikasi senyawa senjata kimia yang mana matriksnya berbeda maka cara preparasi juga akan berbeda.

\section{DAFTAR PUSTAKA}

1. Creasy. W.R, et.al.. 1997, Identification of Chemical - Weapon - Related Compounds in Decontamintaion Solution and Other Matrices by Multiple Chromatography Techniques. J. of chromatography A, 774: $253-263$.

2. Mesilaakso, M., et.al.,2000, Verification of Chemicals Related to The Chemical Weapons Convention. Anal. Chem.: 899 909.

3. Nancy B. munro, Sylvia S. Tamage, Guy D. Griffin, Larry C. Waters, Annetta P. Watson, Joseph F. King, and Veronique Hausechild. The Sources, Fate, and Toxicity of Chemical Warefare Agent Degradation Product. Environ. Health Perspect. 107 (1999) 933.
4. Harvey, D. J., et.al., 1973, Derivatives for the Characterization of Alkyl - and Aminoalkylphosphonates by Gas Chromatography and Gas Chromatography - Mass Spectrometry. J. of Chromatography, $79: 65$ - 74.

5. Creasy, W. R., et.al., 1995, Atomic Emission Detection for the Quantitation of Trimethylsilyl derivatives of ChemicalWarefare-Agent Related Compounds in Environmental Sampels. J. of Chromatography, 709 : 333 - 344.

6. Black. R.M, Read. R.W., 1998, Analysis of degradation products of organophosphorus chemical warfare agents and related compounds by liquid chromatography-mass spectrometry using electrospray and atmospheric pressure chemical Organic Ion. J. of chromatography A, $794: 233-244$.

7. Black, R. M., Muir B., 2003, Derivatisation Reactions in the Chromatographic Analysis of Chemical Warfare Agents and Their Degradation Products. Journal of Chromatography, $1000: 253-281$.

8. Standard Operating Procedure for the Organisation of OPCW Profisiensi Tests. 2006, QDOC/LAB/SOP/PT1.

9. Work Instruction For the Evaluation of the Result of OPCW Proficiency Tests. 2007, QDOC/W1/LAB.

10. Wils, E.R.J., 2005, Chemical Weapons Convention Chemicals Analysis: Gas Chromatography/Mass Spectrometry in Analysis of Chemicals Related to the Chemical Weapons Convention. edited by Markku Mesilaakso: 249 - 279. 


\section{BIODATA}

Evita Boes

dilahirkan di Padang pada tanggal 5 Mei 1958. Penulis menamatkan pendidikan terakhir S2 dibidang Kimia Analitik di Institute Teknologi Bandung pada tahun 1999. Saat ini bekerja sebagai peneliti pada Pusat Penelitian KimiaLIPI Bandung.

\section{Dyah Styarini}

dilahirkan di Pati pada tanggal 30 Oktober 1979. Penulis menamatkan pendidikan terakhir S1 dibidang Kimia Analitik di Universitas Indonsia pada tahun 2001. Saat ini bekerja sebagai peneliti pada Pusat Penelitian Kimia-LIPI Serpong.

\section{Nuryatini}

dilahirkan di Tasik Malaya pada tanggal 29 Juni 1957. Penulis menamatkan pendidikan terakhir S2 dibidang Kimia Analitik di Institute Teknologi Bandung pada tahun 1989. Saat ini bekerja sebagai peneliti pada Pusat Penelitian KimiaLIPI Serpong.

\section{Harry Budiman}

dilahirkan di Sukabumi pada tanggal 15 Juli 1982. Penulis menamatkan pendidikan terakhir S1 dibidang Kimia Analitik di Universitas Padjadjaran Bandung pada tahun 2003. Saat ini bekerja sebagai peneliti pada Pusat Penelitian Kimia-LIPI Serpong. 